УДК 378.147:78.091:7.038.531

DOI:

Володимир Салій, кандидат педагогічних наук, доцент, дочент кафедри народних музичних інструментів та вокалу Дрогобицького державного педагогічного університету імені Івана Франка Наталія Сторонська, кандидат мистецтвознавства, провідний концертмейстер кафедри народних музичних інструментів та вокалу Дрогобииького державного педагогічного університету імені Івана Франка

\title{
ПЕДАГОГІЧНІ УМОВИ ПІДГОТОВКИ ДО КОНЦЕРТНОГО ВИСТУПУ МУЗИКАНТА-ВИКОНАВЦЯ
}

У статті розглянуто методи розв'язання проблеми сценічного хвилювання в процесі підготовки музиканта-виконавия до кониертного виступу. Оскільки музична педагогіка покликана розробляти прогресивні форми освіти, створювати нові методики з метою оновлення навчально-виховного процесу та підвищення його ефективності-однією з найважливіших тенденцій передовоїмузичної педагогіки є прагнення досягти ичілісного формування особистості музиканта-виконавияя, гармонійного розвитку всіх його якостей. Одне із завдань професійного розвитку музиканта-виконавия - иче підготовка до концертного виступу.

Ключові слова: кониертний виступ; музикант-виконавець; сиенічне хвилювання; естрада; педагогічна підготовка.

תim. 8.

Volodymyr Salii, Ph.D.(Pedagogy), Associate Professor, Associate Professor at the Folk Musical Instruments and Vocals Department Drohobych Ivan Franko State Pedagogical University Nataliia Storonska, Ph.D.(Art Study), Leading Concertmaster of the Folk Musical Instruments and Vocals Department Drohobych Ivan Franko State Pedagogical University

\section{PEDAGOGICAL CONDITIONS OF PREPARATION FOR THE CONCERT PERFORMANCE OF THE MUSICIAN-PERFORMER}

The article considers the methods of solving the problem of stage excitement in the process of preparing the musician-performer for the concert performance. Music pedagogy is designed to develop progressive forms of education, to create new methods in order to renew the educational process and increase its efficiency. One of the most important trends in advanced music pedagogy is the desire to achieve a holistic formation of the personality of the musician-performer, the harmonious development of all his qualities. It is possible to improve the upbringing and education of music students in different directions. One of the tasks of professional development of a musicianperformer is preparation for a concert performance.

Preparing a musician-performer to perform at a concert includes a number of important components, provides a wide range of knowledge, skills and abilities. The readiness and ability of a young musician-performer to perform in front of a wide audience is necessary. Practice shows that it is not enough to have the technique of playing a musical instrument. It is also necessary to have special, specific techniques - the technique of mental self-regulation, in the absence of which performances in front of an audience are much less likely to succeed.

To a large extent, success depends on the natural data of a musician-performer, his general and special abilities. At the same time, the ability to own oneself can be developed, and the help of a teacher can play a very important role.

Stage excitement is a natural echo of the very fact of the musician-performer's performance in front of an audience. Affective mental state, which can arise only from one prediction of the difficulties of appearance in front of the listeners, accumulates as you approach this responsible situation.

Stage excitement manifests itself in various forms and forms. It can manifest itself in the form offear, panic; can be transformed into a depressed mood, apathy, despair, etc.

Psychological and pedagogical aspects of preparing a musician-performer for concert performances are insufficiently studied. There is no solid theoretical basis for solving this problem.

Keywords: concert performance; musician-performer; stage excitement; stage; pedagogical training.

П остановка проблеми. Сольний виступ на концерті є особливою формою суспільної роботи музикантавиконавця, яка доволі різниться від усіх інших видів його творчої діяльності. Виконавцеві та його педагогу необхідно мати уявлення про специфіку 


\section{ПЕДАГОГІЧНІ УМОВИ ПДГОТОВКИ ДО КОНЦЕРТНОГО ВИСТУПУ МУЗИКАНТА-ВИКОНАВЦЯ}

мислення і поведінки на естраді, яка орієнтована цілковито на сценічний виступ.

Не без підстави стверджують, що естрадний стан музиканта за своєю суттю багато в чому схожий $з$ типовим самопочуттям людини в обстановці відповідальної публічної діяльності. На самопочуття виконавця під час концерту впливають не лише багато загальних психофізіологічних закономірностей стресового стану, а й художньо-творчі чинники, пов'язані зі складністю досягнення глибини, виразності і цілісності інтерпретації твору, з необхідністю виходу на високий рівень професійної точності і стійкості виконання, артистичності, віртуозності дій, а також з головним завданням активного художнього впливу на аудиторію.

Аналіз досліджень. Проблемі підготовки музиканта-виконавця до виступу на концерті присвячені дослідження видатних музикантів і педагогів - Г. Нейгауза [6], Л. Баренбойма [1], Л. Бочкарьова [2], С. Савшинського та ін. Водночас, психолого-педагогічні аспекти підготовки музиканта-виконавця до концертних виступів вивчені недостатньо. Відсутні міцні теоретичні основи розв'язання цієї проблеми.

Розробкою та визначенням методів розв'язання проблеми сценічного хвилювання в процесі підготовки музиканта-виконавця до концертного виступу у своїх працях займалися такі дослідники, як М. Юник [8, 121-150], Г. Коган [3], Л. Бочкарьов [2] та інші.

Мета статті - розглянути методи розв'язання проблеми сценічного хвилювання в процесі підготовки музиканта-виконавця до концертного виступу.

Виклад основного матеріалу. Діяльність виконавця на естраді - це відповідальний публічний акт нового відтворення музичного твору, тобто породження фантазійного, нереального світу створених композитором образів; своєрідна “ідеальна реальність”, в яку музикант повинен занурити своїх слухачів. Що ж, по суті, нового з'являється у музиканта-виконавця під час концертного виступу? Що служить перешкодою в його діяльності або суб'єктивно сприймається як перешкода, збиває попередню “настройку” виконавського процесу? Що виявляється необхідним, що виводить музиканта на справді високий рівень виконавської майстерності?

Слід виділити два основні чинники. Перший пов'язаний $з$ певними змінами творчої сторони виконання, з підвищенням рівня інтерпретаційних завдань у результаті виникнення спілкування зі слухачем; другий зі значною трансформацією роботи багатьох психофізіологічних механізмів музично-виконавської діяльності.

Розглядаючи перший фактор, необхідно відзначити, що на естраді через появу реального слухача і особливого, дзвінкого простору залу в новому світлі постають сама проблема художньої інтерпретації твору, спрямованість і масштаби втілення музичних образів. С. Майкапар підкреслював “необхідність орієнтації на акустичні умови концертного залу, які особливо доводиться враховувати головним вокальним виконавцям, інструментом яких $є$ голос, що найбільшою мірою страждає від поганої акустики залу, в якому доводиться виступати" [5, 34]. Р. Шуман писав: “Виконання артиста перед публікою або перед окремими особами не одне і те ж, та й сам він стає іншим. Прекрасний, яскраво освітлений зал, блиск свічок, ошатні убори - все це піднімає настрій, як виконавця, так і слухача" $[7,234]$. При збігу даних умовностей, процес звукового розгортання творів протікає абсолютно в іншому руслі. "Коли $є$ контакт, коли публіка слухає з особливим настроєм і увагою, тоді хочеться заради цього моменту віддати їй все найкраще, найпотаємніше, що закладено в тобі, весь музичний талант. Протягом однієї-двохтрьох хвилин сконцентрувати всі свої знання, всю свою роботу, напругу передконцертних днів" стверджував Л. Коган [4, 222].

Стосовно естради можна говорити про виникнення цілісної системи поведінки в концертній ситуації, ступеня вірності організації всього попереднього ходу підготовки, знайденню якнайкращих способів нейтралізації і перетворення від'ємного впливу стресу з метою використання тих виняткових перспектив, які дає виступ музиканта-виконавця.

Одним з особливих станів психіки, що виникають на естраді, $є$ специфічний механізм “роздвоєння” уваги і діяльності під час виконання у концертній обстановці. Це явище виникає через те, що автоматизована діяльність з розгортання стисненого художнього коду творів у реальний, розгорнутий виконавський процес протікає паралельно з передбаченням його результатів, 3 передчуттям музики, причому контроль над цією діяльністю відбувається з відомим відставанням за часом. Свідомість виконавця змушена “працювати" ніби у двох вимірах, що значно активізується при виході на високі рівні творчості, в стані натхнення, коли художній результат часом виявляється новим і несподіваним навіть для самого виконавця. Таке “роздвоєння” на власну художню діяльність і контроль над нею стає найважливішим критерієм вірності протікання 
естрадногопроцесу, співвідношенням неусвідомлюваної діяльності музиканта і високого рівня усвідомлення результатів художньої та технологічної сторін виконання, а також ступеня артистичного впливу на зал.

Стан “роздвоєння” - це прояв високорозвинених емоційно-регулятивних можливостей людини. Його психологічним механізмом є розподіл уваги, що виражається в умінні сприймати, мислити або діяти в даний відрізок часу при наявності двох або більше спрямувань цих процесів. Так, Г. Коган вказував, що при виконанні музичного твору “хвилювання в образі” цілком сумісне з “творчим спокоєм" поза образом" [3, 89].

Творчий “стан роздвоєння” характеризується не тільки високим рівнем функціонування уваги, але й відрізняється динамізмом, стрімкістю протікання усіх психічних процесів: сприйняття, уявлень, мислення, фантазії. Яскрава емоційна насиченість діяльності, творче піднесення під час виконання можуть посилювати продуктивність роботи фантазії, інтуїції і викликати у музиканта бажання змінити ті сторони звучання, які відповідають даному психічному стану, через які він може найцікавіше реалізувати свою виконавську концепцію.

Другий фактор, що позначається на процесі концертного виконання, пов'язаний зі значною трансформацією роботи багатьох психофізіологічних механізмів музично-виконавської діяльності, зокрема, з появою стресового хвилювання, незвичайним станом рухових компонентів ігрового або голосового апарату, а також уваги аж до деформації раніше добре налагодженого контролю над успішним розвитком виконавського процесу. У момент концертного виступу у виконавця відбувається низка психофізіологічних змін: з'являється велика психічна, емоційна, фізіологічна напруга; підвищується або, навпаки, знижується кров'яний тиск і температура; частішає серцебиття; виявляється деяке порушення кровообігу; виникає надмірна стимуляція рухової активності, збільшення тонусу м'язів, порушення природного ритму дихання тощо. Ускладнювати виконавський процес може також гіпервідповідальність, тобто надмірно підвищена вимогливість до себе і до свого мистецтва, що сковує виконавця.

Завищена самооцінка власного виконання, загострені претензії артиста, накладаючись, створюють при концертному виступі природне почуття відповідальності, можуть призводити до порушення окремих сторін виконавства. Передовсім стосується технічної сфери, позаяк виконавець практично ніколи не буває цілком задоволений, скажімо, якістю звуку, виконанням того чи того важкого місця, пасажу та ін., це властиво навіть великим музикантам. Надмірний стан відповідальності підсилює почуття тривоги і невпевненості. Справжньому артисту постійно доводиться доводити і самому собі, і публіці відповідність своєї майстерності та власної завойованої слави.

У виконавців менш високого рангу існує набагато більше приводів для незадоволеності результатами свого виконання, що є досить природним у процесі їхнього творчого розвитку. Подібні сумніви, підкріплені часто досвідом не цілком вдалих виступів, опорами виконавця на стандартні методи “вивчання” творів, пов'язаних 3 механічною пам'яттю. При цьому не до кінця враховується той факт, що на естраді виникають зовсім інші обставини і умови, коли втілення ідеального художнього (слухового) подання до матеріального звукового тексту значно ускладнюється. Безумовно, в такому випадку результат завжди буде гіршим від очікуваного.

Помітну функцію у стабілізації концертного стану має регулярність виступів. Тоді естрадне хвилювання, яке було на кожному попередньому концерті, не встигає піти, а ніби приховано залишається в пам'яті у досить актуальному вигляді. Свідомість тримає його певні структури, оскільки виконавцю відомо про майбутній концерт. 3'являючись знову, естрадне хвилювання має у такому випадку пом'якшений характер і швидко зникає, поступаючись місцем заспокоєнню. Якщо ж у артиста трапляються значні перерви в публічних виступах, то сформований раніше високий естрадний тонус поступово втрачається і йому доводиться заново відчувати всі стадії виникнення і протікання естрадного стресу.

Звичка до інших видів виконання на естраді (по нотах, в ансамблі і т. д.), коли активно включений зоровий фактор, відсутня проблема пам'яті і знімається індивідуальна відповідальність, багатьом артистам також значно ускладнює сольне виконання напам'ять.

Педагогічна підготовка музиканта-виконавця перед концертним виступом рівноцінна за важливістю професійно-виконавській підготовці як такій. Умови виступу на концерті однозначно відрізняються від виконання в домашніх умовах, тому саме концертний виступ є своєрідним випробуванням “на міцність” виконаної “домашньої роботи” над концертною програмою. Лише під час концерту можна визначити якість вивченої програми, технічний та художній рівні музиканта, його психологічну витримку, а також багато іншого. Однозначно, не потрібно 
прирівнювати профпридатність музикантавиконавця до його багатьох різних успішних відкритих виступів. Доволі часто у надзвичайно обдарованих музикантів-виконавців концертний виступ з різноманітних причин завершується сценічним фіаско. Також буває цілком навпаки у деяких ситуаціях, менш обдарований та менш досвідчений музикант-виконавець достатньо добре показує себе на публіці. Але, не зважаючи на це, як ми уже говорили раніше, - виконанням на сцені відбувається перевірка всього комплексу, даного природою, музично-виконавських здібностей, володіння “технічним” потенціалом, психологічної стабільності та ін.

Формувати сценічну стійкість музикантовівиконавцю необхідно з раннього дитинства, а саме одразу з початком занять музикою. Прийнято вважати, що музиканти-початківці, які неодноразово та з успіхом виступали в юні роки на будь-яких сценах, отримують кращу професійно-психологічну витримку в майбутньому, а також простіше долають сценічне хвилювання. Проте цілком категорично з цим погоджуватись не можна, позаяк у багатьох біографічних відомостях відомих музикантів-виконавців однакова кількість свідчень як на користь такої позиції, так і проти неї.

Необхідно вивчати особистісні особливості музиканта-виконавця, його негативні і позитивні сторони його психіки, професійні успіхи, емоційновольову сферу, характер, а також його вміння поводитись на сцені, ступінь професійної витримки. Лише беручи до уваги усі ці дані, потрібно складати індивідуальний план занять. I від стратегії, послідовно вибудованої педагогом, починаючи 3 перших уроків, буде залежати результат навчання.

Одними з основних завдань педагога у процесі навчання $є$ вміння сформувати та виховати в учня позитивні риси характеру, і натомість позбутися негативних, формуючи високий щабель психологічної витримки.

Сценічний стан музиканта-виконавця перед виступом значною мірою залежить також від настрою педагога. Викладач повинен вміти вселяти бадьорість у своїх вихованців. Немає нічого більш безглуздого і більш травмувального, для музиканта-виконавця, ніж вигляд власного наставника, галас до тремтіння, і водночас заклик до спокою і впевненості.

Похвала перед виступом необхідна, нехай вона не завжди буде цілком щирою, існують різні ситуації в педагогіці, де мета виправдовує засоби. $€$, звичайно, ситуації, де похвала протипоказана навіть перед виступом. У цьому випадку лише сам педагог вирішує, що і коли він скаже вихованцю напередодні виходу на сцену.

Закінчивши виступ, музикант-виконавець, передовсім очікує почути думку та оцінку щодо свого виступу від педагога. Беззаперечно, що необхідно підтримати виконавця, віднайти підстави для похвали, незважаючи на певні помарки. Музикант-виконавець повинен відчути, що його наставник радіє з його старань та успіхів.

Детально аналізувати виступ, роблячи певні зауваження та обговорюючи невдалі у ньому місця, найкраще після концерту, в сприятливій обстановці. Знайшовши причину усіх невдач та промахів, потрібно зробити висновки щодо їх виправлення в подальшому. Також дуже важливо налаштувати вихованця об'єктивно ставитися до промахів, розцінювати їх як минуле явище, а не якусь катастрофу, як прикру, але пройдену подію. Він повинен зрозуміти, що його життєва сила не згасати духом, бути оптимістом. Будь-який промах має породжувати не песимістичні роздуми, не вводити у депресію, а створювати бажання в майбутньому виступати краще. Для цього педагогу необхідно ухилятися від розмов про невдачі, а сконцентровувати увагу виконавця на успішних виступах.

Висновки. Отже, діяльність музикантавиконавця - складний, напружений і водночас відповідальний процес. Налаштовуючись до появи на сцені, музикант-виконавець затрачає велику кількість енергії - емоційної, а також фізичної. Щоб визначити слабкі сторони творчої особистості та обрати найкориснішу i найпродуктивнішу методикупсихологічної підготовки до виступу на концерті, необхідно володіти великим обсягом інформаціїщодо цієї проблеми.

Максимальна увага педагога багато в чому може визначити професійний шлях майбутнього музиканта-виконавця: психічна травма або байдужість, що виникли після виступу, здатні призупинити музичну діяльність окремих музикантів-виконавців. Увесь хід передконцертної роботи формує особливості методики організаційно-педагогічних принципів проведення концертного виступу. Їх знання і облік $є$ одним 3 факторів успішної діяльності педагога, невід'ємною частиною його професійної спроможності.

\section{ЛІТЕРАТУРА}

1. Баренбойм Л. Музыкальная педагогика и исполнительство. Ленинград: Музыка, 1974. С. 52.

2. Бочкарёв Л. Л. Психология музыкальной деятельности. Москва, Классика - ХХІ, 2008. С. 220.

3. Коган Г. М. У врат мастерства. Работа пианиста. Москва: Музыка, 1969. С. 89. 
4. Коган Л. Б. Воспоминания. Письма, Статьи. Интервью. Москва: Музыка, 1987. С. 222.

5. Майкапар С. М. Музыкальное исполнительство и педагогика. Челябинск: MPI, 2006. С. 34.

6. Нейгауз Г. Воспоминания. Письма. Материалы. Москва: Имидж, 1992.415 с.

7. Шуман Р. Избранные статьи о музыке. Москва: Музгиз, 1956. С. 234.

8. Юник Д. Г. Виконавська надійність митців музичного мистецтва: концептуальний аспект. Теорія та методика мистецької освіти. Наукова школа Г. М. Падалки. Колективна монографія. Київ: НПУ імені М. П. Драгоманова, 2011. С. 121-150.

\section{REFERENCES}

1. Barenboym, L. (1974). Muzykalnaya pedagogika i ispolnitelstvo [Musical pedagogy and performance]. Leningrad, p. 52. [in Russian].

2. Bochkarov, L. L. (2008). Psikhologiya muzykalnoy deyatelnosti [Psychology of musical activity]. Moscov, p. 220. [in Russian].
3. Kogan, G. M. (1969). U vrat masterstva. Rabota pianista [At the gates of mastery. The work of a pianist]. Moscov, p. 89. [in Russian].

4. Kogan, L. B. (1987). Vospominaniya. Pisma, Stati. Intervyu [Memories. Letters, Articles. Interview]. Moscov, p. 222. [in Russian].

5. Maykapar, S. M. (2006). Muzykalnoye ispolnitelstvo i pedagogika [Musical performance and pedagogy] Chelyabinsk, p. 34. [in Russian].

6. Neygauz, G. (1992). Vospominaniya. Pisma. Materialy [Memories. Letters. Materials]. Moscov, 415 p. [in Russian].

7. Shuman, R. (1956). Izbrannyye stati o muzyke [Selected articles on music]. Moscov, p. 234. [in Russian].

8. Yunyk, D. H. (2011). Vykonavska nadiinist myttsiv muzychnoho mystetstva: kontseptualnyi aspekt [Performing reliability of artists of musical art: conceptual aspect]. Theory and methods of art education. H.M. Padalka Scientific School. Collective monograph. Kyiv, pp. 121-150. [in Ukrainian].

Стаття надійшла до редакції 28.04.2021

УДК 377.6:61

DOI:

Олеся Власій, кандидат технічних наук, доцент кафедри математики та інформатики $i$ методики навчання, докторант кафедри методики початкової освіти Прикарпатського начіонального університету імені Василя Стефаника

\section{МОЖЛИВОСТІ ВИКОРИСТАННЯ ІГРОВИХ ТЕХНОЛОГІЙ ДЛЯ ПІДГОТОВКИ МАЙБУТНІХ УЧИТЕЛІВ ДО ФОРМУВАННЯ ЦИФРОВОЇ КОМПЕТЕНТНОСТІ ШКОЛЯРІВ}

У статті розглянуто проблему компетентнісного підходу до навчання в умовах циифровізації освіти; наголошено на необхідності модернізації форм та методів навчання школярів $i$, відповідно, на важливості підготовки майбутніх учителів до впевненого використання інформаційно-комунікачійних технологій у професійній діяльності; запропоновано використання цифрових технологій для реалізації ігрових методик навчання, зокрема, у вигляді веб-квестів; запропоновано використання сервісу Learning Аррs для розробки інтерактивних завдань веб-квестів, наведено коротку характеристику сервісу та переваги його використання y веб-квестах; запропоновано можливість організаиії веб-квестів засобами пакету сервісів G Suite for Education; наведено приклади впровадження запропонованого підходу у процес підготовки майбутніх учителів інформатики та майбутніх учителів початкових класів у Прикарпатськму начіональному університеті імені Василя Стефаника.

Ключові слова: компетентнісний підхід; інформаційно-комунікаиійні технологї̈; изифрові інструменти; ігрові методики навчання; веб-квест.

Jim. 14.

Olesia Vlasii, Ph.D.(Engineering), Associate Professor of the Mathematics and Informatics and Methods of Teaching Department,

Doctoral Student of the Primary Education Pedagogy Department, Vasyl Stefanyk Precarpathian National University

\section{POSSIBILITIES OF USING GAME TECHNOLOGIES IN PREPARING FUTURE TEACHERS FOR THE FORMATION OF SCHOLLSTUDENTS' DIGITAL COMPETENCE \\ In the article, the problem of competence approach to teaching and learning in the context of digitalization of education is considered. The need of modernization forms and methods of teaching secondary school students is established. The main features of the information and digital competence of a secondary school teacher are considered. The use of information and communication technologies and digital tools, in general, is considered as one of the}

